University of Nebraska - Lincoln

DigitalCommons@University of Nebraska - Lincoln

Faculty Publications, Department of Child, Youth, and Family Studies

Child, Youth, and Family Studies, Department of

$9-1981$

\title{
Social Roles and Moral Reasoning: A Case Study in a Rural African Community
}

\author{
Sara Harkness \\ Harvard University, sara.harkness@uconn.edu \\ Carolyn P. Edwards \\ University of Nebraska-Lincoln, cedwards1@unl.edu \\ Charles Super \\ Harvard University
}

Follow this and additional works at: https://digitalcommons.unl.edu/famconfacpub

Part of the Family, Life Course, and Society Commons

Harkness, Sara; Edwards, Carolyn P.; and Super, Charles, "Social Roles and Moral Reasoning: A Case Study in a Rural African Community" (1981). Faculty Publications, Department of Child, Youth, and Family Studies. 66.

https://digitalcommons.unl.edu/famconfacpub/66

This Article is brought to you for free and open access by the Child, Youth, and Family Studies, Department of at DigitalCommons@University of Nebraska - Lincoln. It has been accepted for inclusion in Faculty Publications, Department of Child, Youth, and Family Studies by an authorized administrator of DigitalCommons@University of Nebraska - Lincoln. 


\title{
Social Roles and Moral Reasoning: A Case Study in a Rural African Community
}

\author{
Sara Harkness, School of Education, Harvard University \\ Carolyn Pope Edwards, University of Massachusetts-Amherst \\ Charles M. Super, School of Education, Harvard University
}

\begin{abstract}
This study explores relationships among moral reasoning (as measured by the Kohlberg scale of moral development), social roles, and cultural context among the elders in a small, traditional Kipsigis community of western Kenya. Six traditional leaders - men who were considered morally outstanding by their neighbors and who were frequently called on to help settle local disputes - were interviewed, using an adapted version of the Kohlberg moral dilemmas; six men who were similar to the leaders in age, education, religion, and wealth but who were not considered moral leaders were also interviewed. The leaders scored slightly but significantly higher than the nonleaders on Kohlberg's scale. All of the men's responses, however, were in the Stages 2-4 range, with no representation of the two highest stages. The cultural values expressed by the men's responses are discussed in relation to their own roles in the community and in relation to the structure of traditional Kipsigis society, and Kohlberg's theory is critically reexamined.
\end{abstract}

Lawrence Kohlberg's (1969) theory of moral development has been used to study moral reasoning in adults as well as children (e.g., Gilligan, 1977; Holstein, 1976; Kuhn, Langer, Kohlberg, \& Haan, 1977). The theory posits six culturally universal stages of moral judgment over the life-span: The lower three usually emerge by adolescence, whereas the upper three develop, if at all, during middle to late adolescence or adulthood (Kohlberg \& Kramer, 1969). Like Piaget's stages of cognitive development, Kohlberg's stages of moral development have their own internal coherence, and they are arranged in ascending order of complexity;

Field work and preparation of this article were supported in part by grants from the Carnegie Corporation of New York, the William T. Grant Foundation, and the National Institute of Mental Health (Grant 1 -ROH-MH33281). All statements made and views expressed are the sole responsibility of the authors.

Charles M. Super is now at The Judge Baker Guidance Center and the Harvard School of Public Health. Requests for reprints should be sent to Sara Harkness, who is now at the Department of Psychiatry, Harvard Medical School, and The Judge Baker Guidance Center, 295 Longwood Avenue, Boston, Massachusetts 02115. each stage represents a differentiation of the basic elements in the preceding stage and their reintegration into a new, more logically powerful structure (see Kohlberg, 1969).

Kohlberg's claim that his scheme is culturally universal is based on three premises. First, the structure of moral judgment is transformed through the six stages from simpler to more advanced forms in a logically necessary order. Second, the moral dilemmas used in eliciting judgments center on universal issues such as life, property, authority, and affectional roles. Finally, all cultural groups possess systems of values that have certain basic formal and functional properties in common (Kohlberg, 1971, p.175). For example, all cultures distinguish between impulse and desire on the one hand and behavior that is justified and "right" on the other.

Nevertheless, because the stages were originally derived from interviews of male Americans, they have been criticized as ethnocentric and biased (Bloom, 1977; Gibbs, 1977, 1979; Gilligan, 1977; Simpson, 1974; Wilson, 1976). These critiques suggest that the upper end of 
Kohlberg's scale is arbitrary and vulnerable to attack in a way that is different from the lower end of the stage sequence. Findings from a number of studies conducted in non-Western settings suggest that moral judgment Stages 5 and 6 , and Stage 4 as a person's dominant stage, are not seen in traditional adults from small, faceto-face communities such as exist in peasant or tribal societies (cf. Kenyan studies by Edwards, 1975, 1978; Turkish studies by Turiel, Edwards, \& Kohlberg, 1978; Bahamian studies by White, 1975; White, Bushnell, \& Regnemer, 1978; British Honduran studies by Gorsuch \& Barnes, 1973; Nigerian studies by Magsud, 1977a, 1977b,1979; Indian studies by Parikh, 1980). Edwards $(1975,1980)$ argued that the upper stages are not likely to be found in all cultures because they correspond to modes of conflict resolution in complex societies. According to Edwards, the reasoning of the lower stages appears compatible with a much greater variety of social organizations, and one might expect at least some individuals in all cultures to reason in ways corresponding to these stages.

Another problematical aspect of Kohlberg's theory is its relationship to other measures of people's moral functioning, such as moral standing with peers and actual moral behavior. Although researchers with a behavioral perspective might disagree (e.g., Kurtines \& Greif, 1974; Burton, Note 1),Kohlberg $(1969,1973)$ hypothesized that people with "conventional" (Stages 3 and 4) moral reasoning adhere to cultural norms of "good conduct" more consistently than do people with "preconventional" (Stages 1 and 2) moral reasoning. Experimental studies of behavior in moral conflict situations (Krebs, 1967; Krebs \& Rosenwald, 1977; McNamee, 1977) as well as studies of peer reputation (Harris, Mussen, \& Rutherford, 1976; Keasey, 1971) have demonstrated some relationships between these behavioral or social variables and moral reasoning. We know of no published evidence, however, that can speak to the issue of how moral reasoning may be related to moral reputation or behavior in non-Western cultures.

The research described here addresses the relationship between moral reasoning and so- cial roles. Specifically, we ask whether people who occupy roles as civic leaders and arbiters of justice in their own community use styles of moral reasoning that differ from others who are not "moral leaders." More broadly, we consider the relationship between individual moral development and sociocultural context.

The setting for the present study was a rural Kipsigis community of western Kenya. The Kipsigis are a Highland Nilotic people numbering about half a million. Traditionally pastoralists and simple agriculturalists, the Kipsigis today have adapted to the modern national economy through cash production of milk, maize, pyrethrum, and tea. A relative abundance of land has allowed most Kipsigis men to remain farmers at home rather than seek salaried jobs away, and family herds still suffice for the traditional paying of brideprice. Other features of the traditional life-style also persist: Adults in Kokwet, as we refer to the community studied, have had little or no schooling, and adolescents almost unanimously choose to undergo the traditional circumcision or clitoridectomy rites that mark the transition to adulthood. Despite half a century of missionary activity in the area, most families have made no more than a nominal conversion to Christianity, and polygyny is still the preferred household style for most men.

Kipsigis society is particularly well suited to a consideration of relationships between social roles and Kohlberg's scale of moral reasoning. Unlike modern Western society, with its specialization of roles and responsibilities, traditional Kipsigis society provided for the settlement of disputes at the neighborhood level through meetings of its members. With the imposition of the British judicial system during the colonial period and its subsequent continuation under the Kenya national government, authority for handling the more serious crimes has been removed to the police and courts. Nevertheless, this still has left a large range of lesser disputes among family members and neighbors to be settled at the community level.

The process of dispute settlement in Kokwet fits the general pattern that has been described for sub-Saharan groups lacking superordinate 
systems of authority (Bohannon, 1957; Gluckman, 1959; Gulliver, 1963; Saltman, 1977). In these communities, the only force behind the settlement of disputes is public opinion; consequently, a prime characteristic of the dispute settlement process is the participation of the community. The main goal of dispute settlements in communities such as Kokwet is not to uphold an abstract principle of justice but rather to bring the disputants into social equilibrium with each other and thereby reestablish peace in the community. For this reason, the principle of fairness is mitigated by other factors such as the relative status of the disputants and a sense of realism about what kind of reparations the two parties will be willing to offer or receive. Although this set of factors and final decision might differ somewhat from Western models, there seems to be no reason to assume that the process of moral reasoning involved in Kipsigis dispute settlements differs from the process that the Kohlberg interviews are meant to elicit. Indeed, the cases that came up during our 3 years' residence in Kokwet were similar to the Kohlberg moral dilemmas in having a complex set of rights and wrongs on each side. In one case, two grown sons beat their father out of anger that the father refused to share his land with them. The principle of paternal authority was badly violated, but the father had failed in his responsibility to provide land for his sons. Who was right and who was, in Kipsigis terms, "mistaken"?

The process of dispute settlement in Kokwet is one in which all members of the community participate at times, whether as disputants, mediators, or quiet members of the group. The roles of active leadership in these meetings, however, are held by the boisiek (s. boiyot), or "senior men," of the community. As this term implies, boisiek are well-established heads of household, thus usually (though not always) somewhat older. There are, however, wide variations in the extent to which individuals in this category are called on to help settle disputes. A boiyot whose opinion is most sought and whose leadership is most valued is one who "speaks the truth" at dispute settlement meetings; he sees to the heart of a problem and presents his insights with skill and tact. $\mathrm{He}$ is a master of diplomacy, speaking in such a way as to elicit an apology rather than defensiveness from the wrong-doer. Moreover, his own behavior outside of the meetings does not betray his words. He does not deceive people about his own intentions, and he does not use any personal power derived from community leadership positions to enhance his own wealth. Rather, he works for the good of the community.

The social role of leadership in dispute settlements appears to require verbal and rhetorical skills, powers of intellectual reasoning, and recognized moral integrity. Does the differentiation of this role in a traditional African community correspond at all to the kinds of variation formalized in the moral judgment scale? Specifically, do men in Kokwet who play preeminent roles in community dispute settlements score higher on the moral judgment interview than other men from the community who participate to a lesser degree in the settlement of disputes? The answers to these questions should be informative in relation both to claims of cultural universality of the Kohlberg scale and to the question of its relationship to the social dimension of reputation and (indirectly) behavior.

\section{Method}

\section{Subjects}

All of the men who participated in the study were residents of Kokwet, a community of 54 households that was the locus of ethnographic and psychological research by Harkness and Super from 1972 to 1975. Although the sample was limited by the size of the community, it had at least two assets not usually present in psychological research. First, the universe represented by this sample was highly consistent. Second, a great deal of formal and informal information on each of the subjects was available.

The sample consisted of 12 men: 6 moral leaders and 6 nonleaders matched as closely as possible for age, education, religion, and wealth. The men chosen for the moral leader group were people who, in the judgment of the ethnographers and a local assistant, were the most highly respected men of the community. These men were frequently asked to help settle disputes, and they often held official positions of authority as well (e.g., deputy to the local subchief, treasurer of the community self-help society, or member of the school committee).

Subsequently, all of the subjects were asked who, in their opinions, were the "most respected and honest men of Kokwet." Members of the leader group were named an average of 5.1 times (range 1-9) by the 10 men who re- 
sponded to this question. Members of the nonleader group were mentioned an average of only .5 times (range 0-2). These responses reflect the fact that moral leadership in Kokwet was a relative, not absolute, status, held to varying degrees by different men. Our group designations corresponded well to the subjects' opinions, with one interesting exception: the nonleader who was named twice as one of the most respected men of Kokwet. This man enjoyed an equivocal status in the community: Because of his wide experience in the world outside Kokwet and his political acumen, he often held positions of official responsibility. $\mathrm{He}$ was not generally respected for his moral qualities, however, and was never, to our knowledge, asked to help settle disputes outside his own family.

The leaders and nonleaders were matched for background variables to minimize the effects of these factors on the results of the study. Both age and socioeconomic status have been related to performance on the moral judgment scale in American, Turkish, and Kenyan adults (e.g., Edwards, 1978; Kohlberg \& Kramer, 1969; Turiel, Edwards, \& Kohlberg, 1978). Religion-specifically the degree of affiliation with Western-introduced Christianity-has proved to be a strong predictor of attitudes and behavior in other domains among the people of Kokwet.

The measures of age and education, recorded in years, are based on self-reports. Wealth is measured inversely as the size of the household's outstanding debt to the Kenya Government for purchase of land in the settlement scheme, according to official records. Religion is based on self-reports, expressed on a 4-point scale constructed to reflect locally acknowledged variation in degree of conversion to Christian values and life-style.

It was not possible to match each pair of leaders and nonleaders perfectly on all four of the background variables, but statistical comparison showed the two groups to be equivalent in mean values, $t(10)=.33,-.74,1.14$, and .32 for age, education, religion, and wealth, respectively; $p$ is nonsignificant. The leaders were on the average slightly older, poorer, less educated, and more Christianized than was the nonleader group but not significantly so. There was, however, wide variation within both groups on three of the four variables. The age of the subjects ranged from 28 years to 74 years. Half the men had never attended school, whereas the remainder had from 4 to 8 years of primary education. Half the men had no Christian affiliation; of the others, three were nominal Christians, and three were more committed Christians. Variation in wealth was not great because all of the men had received equal plots of land and equal numbers of livestock when they moved to Kokwet only 10 years before.

\section{Interview}

The moral judgment interview included three hypothetical moral dilemmas accompanied by a set of questions for discussion. The dilemmas were standard Kohlberg stories adapted for the Kenya setting. The first story presented the problem: Should a boy obey his father and give him some money he had earned himself when the father had promised the boy he could keep it? The second story posed the dilemma: Who did worse - a boy who stole money from a store or his brother who conned a trusting old man out of an equal amount? The third story asked: Is a man right or wrong to steal a drug to save his dying wife when he could not obtain the drug legally?

The men were interviewed at their homes by the first author, with the help of a local woman who acted as interpreter. The task was introduced by explaining to each man that he was going to be told three problem cases such as he might hear in a community dispute settlement meeting. He, as a boiyot, would be asked to judge what was right and what was wrong. All of the men readily accepted this task and became quite involved in giving their judgments.

\section{Scoring}

The interviews were tape recorded and later transcribed directly into English by a bilingual Kipsigis male college student. The translations were checked and corrected by the first author. Using the Global Method (Kohlberg, 1958), the second author scored the dilemmas without knowledge of the subjects' identities. The interviews were later scored twice, independently, by experts in the newer Standard Scoring Method (Colby, 1978; Kohlberg et al., in press). The second author worked with the other raters to clarify specific cultural meanings for critical phrases that recur in the interviews. For example, when Kipsigis speakers answer a question concerning what a father should do for his son by saying simply that "he must educate him," they need to be understood as referring to the strongly held Kipsigis value that a father must pay his children's school fees, not as necessarily making a more general statement that a father should "guide" and teach his son in many aspects of life. These two interpretations have different implications for stage scoring.

Reliability of the two standard scorings was .77, and all of the subjects were scored within a half stage by the two scorers. The two sets of standard scores and the global scores yielded the same conclusions upon statistical analysis; that is, each showed the same pattern of group differences and correlations with independent variables. The data presented here are derived from the standard scoring for which the most detailed exchange of cultural information took place.

\section{Results}

The group of moral leaders obtained significantly higher Moral Maturity Scores than did the group of nonleaders, matched pairs $t(5)=$ $3.68, p=.01$, two-tailed. Of the six matched pairs of men, only one nonleader scored higher than did the corresponding leader; this was the man who had received two nominations as a "most respected" man of Kokwet. The entire group of 12 Moral Maturity Scores varied from a low of 257 to a high of 321; Stages 2 and 3 clearly predominated in the responses, with 
some usage of Stage 4 found for only four men, three of them leaders.

The index of community moral reputationthe number of times mentioned as one of the "most respected men of Kokwet"-correlated strongly and significantly with the Moral Maturity Scores, $r(11)=.72, p=.01$, two-tailed. The social background variables (age, education, wealth, religion), however, were not found to relate significantly to Moral Maturity Scores, $r(11)=.15,-.02, .15$, and .47 , respectively. Thus, although these four factors may contribute to status in the Kokwet community, they were not by themselves good predictors of the scores of moral reasoning.

Although the leaders and nonleaders were discriminable in terms of the underlying stages of their reasoning, it is useful to note that they did not differ in terms of the sides they took in resolving the dilemmas. In response to the father-son story, all six of the nonleaders and five of the leaders agreed that the boy should give up the money. All 12 men in the sample agreed that stealing was worse than fraud, as shown by their responses to the two brothers story. Finally, in response to the drug dilemma, four men in each of the two groups said that it was right to steal the drug, and two men in each group said that it was wrong.

\section{Discussion}

The differences between the leaders and nonleaders can be discussed in relation to three key areas: authority, reciprocity, and conscience. The higher scores of the leaders derived from the fact that they approached these issues with a view to the good of the whole community, not just their own immediate benefit, and that they, more often than the nonleaders, described the control of behavior as generated from within oneself.

\section{Authority}

The area of authority is illustrated in the different ways the leaders and nonleaders discussed the important masculine role of head of the household. All of the men agreed that children should always obey and respect their fa- ther, but in the eyes of the leaders, a man should command natural respect through his own superior moral qualities. His authority should be maintained through being reasonable and nonarbitrary, and he should teach his children to obey willingly for the common good of the family. In the words of some of the leaders:

When your children do not refuse to do what you tell them, then you can be sure that the order is acceptable to them. They like it because it is a fair demand. (Leader A, Stage $3[4]^{1}$ )

The father is the doer and the leader. He is the one who has to do better than everyone else and set the example. ... (Leader B, Stage 3 [4])

If my son doesn't follow my words [advice], he maybe lost to the world since he and I won't be understanding [that is, cooperating with] each other. ... You convince him by .telling him, "Do this sort of thing because this will earn us our living." . . . And so the child will comply thereafter since you did not shout at him. (Leader C, Stage 3)

According to the nonleaders, however, the head of household was simply a strong man, a ruler:

James [in the father-son story] should give the money to his father because the father is a big person. (Non-leader F, Stage 3 [2])

The father has the right to control his children in everything. You have to direct them in what they do because they are your children. . . They should not overrule you but instead they should adhere to what you tell them because you are the head, the leader for them. (Nonleader C, Stage 3 [2])

\section{Reciprocity}

Reciprocity as described by the leaders of Kokwet is the focal point of Kipsigis moral order. The value of reciprocity is explained by the leaders in the context of the family, whose members help each other in a spirit of cooperation and gratitude, not of strict accounting of benefits given and received:

A child has to give you what you ask for just in the same way as when he asks for anything you give it to him. Why then should he be selfish with what he has? A parent loves his child and maybe James [in the father-son story] refused without knowing the need of helping his father. ...

\footnotetext{
${ }^{1}$ The scores are the subjects' global scores for their overall interview based on the Standard Scoring Method. The major stage is indicated outside the brackets; the minor stage, if present, within the brackets. Letter designations for the leaders and nonleaders reflect matched pairs (e.g., Leader A is matched to Nonleader A).
} 
By showing respect to one another, friendship between us is assured and as a result this will increase the prosperity of our family. (Leader D, Stage 3)

The father is testing James by asking him for the money, and if James gives him that money, the father will know that they are one, in unity. He will know that he has a goodhearted child. (Leader E, Stage 3)

The leaders also apply this idea of reciprocity to relations among fellow community members. Here it takes on aspects of the Golden Rule, doing to others what you would have them do to you:

It is not bad for John [in the two brothers story] to borrow the money because even though he did not intend to return it, still I will not lay a curse on him. He will some day remember the loan when his brain opens and he becomes wise. Now he is still young. (Leader C, Stage 3)

Reciprocity as described by the leaders draws a distinction between relations among people who are socially connected and outsiders:

In the past, people used to raid cattle from Kisii people, Luo people, or Masai people. ... That act was blessed and the cows multiplied considerably. . . . But it is a sinful thing if you steal from someone you eat with, someone with whom you have shared food. Even if he is your enemy, as long as he is of your tribe it is bad to steal from him because you have eaten with him. (Leader F, Stage 3 [2])

Thus the Kokwet leaders' idea of reciprocity is based on ideals about the functioning of the social group. In contrast, the nonleaders describe reciprocity as a much more concrete exchange.

It wasn't good of James to refuse [to give his father the money]. He should have given it to him so that his father could have been overwhelmed with joy and therefore James would receive blessings from his father. (Nonleader E, Stage 3)

If Joseph didn't love his wife, then it was not necessary for him to steal the medicine for her.. . . We sometimes say, or hear people say, "Why doesn't this person die so that we may have no more troubles?" Because the person is a nuisance. (Nonleader F, Stage 3 [2])

\section{Conscience}

The idea of conscience, as described by leaders and nonleaders, varies from an inner voice, or self-judgment, to an outwardly oriented concern about wrongdoing and fear of punishment or disapproval. Conscience as an inner voice or self-judgment was best expressed by one of the leaders:

You remain unhappy because you have something in your heart that will draw you to a shadow of being afraid of something that you have done to someone else. Because you will charge yourself according to your heart that you were not right at that time. (Leader B, Stage 3[4])

Another leader put forward an inward-looking view of conscience insofar as he described guilt as a self-inflicted punishment, a voluntary withdrawal from society. Banishment was a traditional Kipsigis response to a chronic wrongdoer:

When a person does evil and people speak of it against him, he keeps away from company and goes to lose himself in the bush because he no longer wants to be seen by people. (Leader C, Stage 3)

Most men, however, displayed approval- or punishment-oriented concepts of conscience:

When one hears someone talking about him saying, "Oh, why did he do that?" then his heart is frightened.... A person realizes that something is bad only when others have seen him. (Leader E, Stage 3)

When a person is grown-up, he knows about right and wrong and so when he realizes that he has done some-thing bad, he goes to make an apology to some of the elders . . . and so he can be excused. His heart does not feel well so he begs for forgiveness. (Nonleader B, Stage 3[2])

Stealing is a sin because after you have stolen you remember it in your mind when you are very sick. "Maybe God is punishing me because I stole. . . . You are all the time in a bad condition-worried, or rather, in discomfort." (Nonleader E, Stage 3)

The elders and nonelders differed in the relative emphases that they placed on different aspects of authority, reciprocity, and conscience. To varying extents, however, all of the men of Kokwet described a coherent moral order on which their community is built. This order entails logical sequences of moral and social relationships and rests on certain assumptions about the nature of society. Adherence to the community norms of authority, both by subordinates and those in command, is seen as the basis of social order. In a family or community where authority is justly exercised and duly obeyed, all members carry out their reciprocal obligations in a spirit of generosity, or "unity," and understanding. The smooth functioning of the group effort, in turn, leads to happiness 
and economic prosperity. In this form of social order the leaders play an authority role at the community level similar to the role that heads of household play at the family level. This form of social control is probably related to the comparatively infrequent expression of guilt as an inner voice. In a social setting where most people live out their lives under the close supervision of family and community elders, only the elders themselves need develop a strong sense of inner control. It is worth noting, in this context, that the punishment-oriented responses of the leaders quoted above obviously referred to feeling states that they attributed to othersspecifically, to inexperienced young men. Their own role, implicitly or explicitly, was to be the monitors and judges of these younger or less wise people. Given this differentiation of social roles within a single community, the highly abstract, internalized sense of guilt common in Western society would be superfluous for most people (Edwards, 1975; Levy, 1972; Whiting, 1959).

The moral order drawn by the men of Kokwet depends on two conditions: that the community be small and that its membership remain stable over a period of many years. Smallness ensures that all members of the community know each other and therefore contribute to the network of mutual obligations and controls. Stability over time guarantees that individual members continue to carry out their mutual obligations to each other. These conditions explain why all of the men thought that stealing was incomparably worse than fraud. Stealing from a member of one's community is a drastic violation of the norm of reciprocity on which the whole community depends for survival. The harm done by fraud, on the other hand, can always be repaired because the malefactor is known to the community; even if the thief does not intend to repay the debt, social pressure will eventually force the repayment.

Given this pattern of relationships, the traditional system of dispute settlement that prevails in Kokwet works well. The values attached to authority demand that a dispute be settled in favor of the person with higher status, regardless of the intrinsic merits of the case. At the same time, however, the value of "unity" in reciprocal relationships makes it necessary that the solution of any conflict be acceptable to the person of lower status. The apparent contradiction between these two needs is probably resolved through informal recognition of the lower status person's complaint. The unofficial position of the leaders of the community actually results in their judgment carrying moral weight as the best expression of the community's values. That is, the leaders of Kokwet are asked to preside over dispute settlements because they are regarded as wiser and better than the other men; if a man so regarded were to act in less admirable ways, his status and role in the community would be adjusted accordingly.

\section{Summary and Conclusions}

Critics of Kohlberg have claimed that stages of moral judgment have little to do with social reality. Our research, on the contrary, has demonstrated a significant relationship between a social indicator - a person's status as a moral leader in the community-and responses to moral dilemmas. The moral reasoning of the leaders and nonleaders differed not in the sides they took in resolving moral dilemmas but rather in the modes of reasoning that they used in reaching their conclusions. "Conventional"(Stages 3 and 4) reasoning, the mode used preferentially by the leaders, seems befitting of their role as moral spokesmen for the community. As contrasted with "preconventional" (Stages 1 and 2) reasoning, conventional reasoning makes a clear distinction between what someone might want to do or "would" do and what a person ideally "should" do. Obeying society's standards is perceived as a goal in its own right, not simply as a way of obtaining desirable practical consequences for oneself. This larger perspective would seem to be a necessity for effective leadership in the settlement of disputes among individuals.

But why are even the leaders of Kokwet only at Stages 3 and 4? Why were Stages 5 and 6 not apparent in their interviews? We believe that conventional modes of reasoning fit well 
with the assumptions of a small, face-to-face society based on close and continued contact among people, stable authority of older over younger, and networks of cooperation and reciprocal obligation. Stages 5 and 6, on the other hand, correspond to the social organization and processes of control characteristic of societies with superordinate justice systems. The moral reasoning of Stages 5 and 6 assumes, first, a fixed code of law and a formal judicial process, and second, a differentiation between government and those who govern. Social control in Kokwet, on the other hand, is exercised through community leaders who serve at the will of the people in the most immediate sense. Dispute settlement is based not on the need of each individual for "fair" or equal treatment by the law but rather on the need of the community for maintaining social equilibrium. Kohlberg (1971) argued that his six stages represent a scale of increasing adequacy of moral judgment for all individuals regardless of social context; we suggest, on the contrary, that the upper stages of the moral judgment scale are an abstraction of the ways in which Western concepts of law and government have evolved in response to the requirements of social heterogeneity and a more distant government. When viewed across different cultural contexts, differences in moral thought and behavior may reflect adaptations to the social functions they regulate rather than individual developmental differences.

\section{Reference Note}

${ }^{1}$ Burton, R. V. Assessment of moral training programs: Where are we going? Invited address given at the meeting of the American Psychological Association, Washington, D.C., September 1976.

\section{References}

Bloom, A. H. Two dimensions of moral reasoning: Social principledness and social humanism in cross-cultural perspective. Journal of Social Psychology, 1977, 101, 29-44.

Bohannon, P. Justice and judgment among the Tiv. London: Oxford University Press, 1957.
Colby, A. Evolution of a moral-developmental theory. In W. Damon (Ed.), Moral development: New directions for child development (No. 2). San Francisco: Jossey-Bass, 1978.

Edwards, C. P. Societal complexity and moral development: A Kenyan study. Ethos, 1975, 3, 505-527.

Edwards, C. P. Social experience and moral judgment in East African young adults. Journal of Genetic Psychology, 1978, 133, 19-29.

Edwards, C. P. The development of moral reasoning in cross-cultural perspective. In R. H. Munroe, R. L. Munroe, \& B. B. Whiting (Eds.), Handbook of cross-cultural human development. New York: Garland Press, 1980.

Gibbs, J. C. Kohlberg's stages of moral judgment: A constructive critique. Harvard Education Review, 1977, 47, 43-61.

Gibbs, J. C. Kohlberg's moral stage theory: A Piagetian revision. Human Development, 1979, 22, 89-112.

Gilligan, C. In a different voice: Women's conception of the self and of morality. Harvard Education Review, 1971, 47, 481-517.

Gluckman, M. Custom and conflict in Africa. New York: Free Press, 1959.

Gorsuch, R. L., \& Barnes, M. L. Stages of ethical reasoning and moral norms of Carib youths. Journal of Cross-Cultural Psychology, 1973, 4, 283-301.

Gulliver, P. H. Social control in an African society. Boston: Boston University Press, 1963.

Harris, S., Mussen, P., \& Rutherford, E. Some cognitive, behavioral, and personality correlates of maturity of moral judgment. Journal of Genetic Psychology, 1976, 128, 123-135.

Holstein, C. B. Irreversible, stepwise sequence in the development of moral judgment: A longitudinal study of males and females. Child Development, 1976, 47, 51-61.

Keasey, C. B. Social participation as a factor in the moral development of preadolescents. Developmental Psychology, 1971, 5, 216-220.

Kohlberg, L. The development of modes of moral thinking and choice in the years 10 to 16 . Unpublished doctoral dissertation, University of Chicago, 1958.

Kohlberg, L. Stage and sequence: The cognitivedevelopmental approach to socialization. In D. Goslin (Ed.), Handbook of socialization theory and research. Chicago: Rand McNally, 1969. 
Kohlberg, L. From is to ought. In T. Mischel (Ed.), Cognitive development and epistemology. New York: Academic Press, 1971.

Kohlberg, L. The claim to moral adequacy of a highest stage of moral judgment. Journal of Philosophy, 1973, 70, 630-646.

Kohlberg, L. et al. Assessing moral stages: A manual (The scoring manual). Cambridge, England: Cambridge University Press, in press.

Kohlberg, L., \& Kramer, R. Continuities and discontinuities in childhood and adult moral development. Human Development, 1969, 12, 93-120.

Krebs, R. L. Some relationships between moral judgment, attention, and resistance to temptation. Unpublished doctoral dissertation, University of Chicago, 1967.

Krebs, D., \& Rosenwald, A. Moral reasoning and moral behavior in conventional adults. MerrillPalmer Quarterly, 1977, 23(2), 77-87.

Kuhn, D., Langer, J., Kohlberg, L., \& Haan, N. S. The development of formal operations in logical and moral judgment. Genetic Psychology Monographs, 1977, 95, 97-188.

Kurtines, W., \& Greif, E. B. The development of moral thought: Review and evaluation of Kohlberg's approach. Psychological Bulletin, 1974, 81, 453-470.

Levy, R. J. Tahiti, sin, and the question of integration between personality and sociocultural systems. In W. Muensterberger \& S. Axelrad (Eds.), The psychoanalytic study of society (Vol. 5). New York: International Universities Press, 1972.

Magsud, M. The influence of social heterogeneity and sentimental credibility on moral judgments of Nigerian Muslim adolescents. Journal of Cross-Cultural Psychology, 1977, 8, 113-122. (a)

Magsud, M. Moral reasoning of Nigerian and Pakistani Muslim adolescents. Journal of Moral Education, 1977, 7, 40-49. (b)
Magsud, M. Resolution of moral dilemmas by Nigerian secondary school pupils. Journal of Moral Education, 1979, 9, 36-44.

McNamee, M. Moral behavior, moral development and motivation. Journal of Moral Education, 1977, 7, 27-31.

Parikh, B. Moral judgment development and its relation to family factors in Indian and American families. Child Development, 1980, 51, 1030-1039.

Saltman, M. The Kipsigis: A case study in changing customary law. Cambridge, Mass.: Schenkman, 1977.

Simpson, E. L. Moral development research: A case study of scientific cultural bias. Human Development, 1974, 17, 81-106.

Turiel, E., Edwards, C. P., \& Kohlberg, L. Moral development in Turkish children, adolescents, and young adults. Journal of Cross-Cultural Psychology, 1978, 9, 75-86.

White, C. B. Moral development in Bahamian school children: A cross-cultural examination of Kohlberg's stages of moral reasoning. Developmental Psychology, 1975, 11, 535-536.

White, C. B., Bushnell, N., \& Regnemer, J. L. Moral development in Bahamian school children: A three-year examination of Kohlberg's stages of moral development. Developmental Psychology, 1978, 14, 58-65.

Whiting, J. W. M. Sorcery, sin and the superego: A cross-cultural study of some mechanisms of social control. In M. R. Jones (Ed.), Nebraska Symposium on Motivation (Vol. 7). Lincoln: University of Nebraska Press, 1959.

Wilson, R. W. Some comments on stage theories of moral judgment. Journal of Moral Education, 1976, 5, 241-248. 